\section{Technology Of Educational Process In School Technology Education}

\section{M.Kh. Shomirzayev}

PhD, Associate Professor, Termez State University, Termez, Uzbekistan

\author{
G OPEn ACCESS \\ The American Journal of \\ Social Science And \\ Education Innovations \\ JULY 2020 \\ Page No.: 212-223 \\ Volume-II Issue-VII \\ PUBLISHED: 30 JULY 2020 \\ www.usajournalshub.com/inde \\ x.php/tajssei \\ Copyright: Original content \\ from this work may be used \\ under the terms of the \\ Creative Commons Attribution \\ 4.0 licence.
}

\begin{abstract}
The article describes the essence of sending students to the profession through the technologicalization of the educational process in order to increase the effectiveness of the organization of "Technology" lessons in secondary schools.
\end{abstract}

Keywords: school, class, group, educator, pupil, pedagogy, upbringing, education, method, process, technology, planning, profession, efficiency, patriotism, national pride.

\title{
Introduction
}

The issues of improving the efficiency of the organization of "Technology" lessons, teacher training have been studied in detail, useful tips and methodological recommendations have been provided. Using such recommendations, we would like to try to interpret the use of innovative pedagogical technologies in the planning and conduct of "Technology" lessons in general secondary schools. Because the effectiveness of the subject 
"Technology" taught in general secondary schools depends, first of all, on the level of preparation of teachers for this subject, how they plan to conduct classes, and, and finally, directly related to its implementation. Therefore, how to plan and prepare for training is the first and most important factor in improving the effectiveness of training. At the same time, of course, we believe that the use of innovative pedagogical technologies in the classroom is especially important in increasing the activity of students and the effectiveness of lessons.

The subject of modern pedagogy imposes on the teacher a comprehensive view of man, his place and role in society. The purpose of education is to make young people perfect, to bring them up in the spirit of patriotism and national pride, to instill in them the ideas of humanity, but, as we all know, the ideas of the infinity of human potential development, ethnogenesis is coming in and has greatly expanded and enriched children's understanding of nature. Therefore, school work leads to new approaches to the educational activity of the teacher, and their meaning is reflected in the education of the new person.

As the President said: "If we do not bring up our children properly, if we are not aware of their behavior and mood every day, every minute, if we do not teach them science and profession, if we do not find a decent job, this deposit will be rich. We can give it away "1.

\section{The Main Findings And Results}

The work of an educator is a hard and selfless work in the way of educating a perfect person, which has a deep humanitarian nature and can be entrusted only to the devotee of his profession². 
Nowadays, upbringing experience and evaluative feedback should be understood and accepted not as a one-sided transition of older generations to a younger generation, but as mutual support and cooperation between adults and children in the field of coexistence.

The social and spiritual environment of the younger generation is constantly changing. Production requires self-awareness and self-improvement in the business world, in social life, in relationships. The problem of forming a free, mature personality requires the transfer of educational work in educational institutions to the rails of pedagogical technology. This process will not be easy, because the whole system of education, which is considered and implemented on a voluntary basis, must be transformed into a strictly science-based pedagogical system. In fact, the elements of social experience (knowledge, skills, creative activity, etc.) are related to the objective being - the product of the pedagogical process and within a particular pedagogical system. What is the essence and content of YAPT in education today? This is primarily reflected in the nationalization of the content of education ${ }^{3}$. At the same time, we need to see the content of education of the younger generation in the knowledge of our past, the rich history, the sources of our culture, which are the basis for the development of world science, and the achievements of modern science. In education, forgetting the national spirit of the people, the history of the past - undermines the formation of national pride, the ideology of independence.

At the same time, ignorance of world civilization, scientific progress, and focus only on nationalism are detrimental to the development of our independent Republic. Therefore, the only right way is to use the achievements of science and technology in the past and in educating the younger generation. 
forms, means and methods, in short, the search for new educational pedagogical technologies, combining them in each case.

The criteria for assessing the effectiveness of the results of the pedagogical system "Educator $\longleftrightarrow$ trainee" are not only the availability of the educator's work plan, proper documentation, organization of children's activities, but also the behavior of each child in the classroom, community, initiative, such as the ability to choose the right occupation, ability, emotional health, vitality, kindness to friends, humility, satisfaction with the attitude of teachers to children. Recently, this has been supplemented by the provision of educators with advanced technologies, as the importance of technology in the profession is undoubtedly great.

Description of some pedagogical technologies used in educational work. In pedagogy, you will learn about the methods and tools used in educational work, their forms, and their types. Now, we will try to determine the role of elements of pedagogical technology in the system of educational work.

The main elements of pedagogical technology in educational work are: methods and techniques of education; educational tools; forms of organization of educational work; student unions. These can be divided into the following groups according to the technology used in school education ${ }^{4}$ :

1. Technologies that shape social consciousness in children (pedagogical influence, conversation and storytelling, role modeling).

2. Technologies for the formation of social behavioral experiences in children's activities (training through exercises, organization of games, demands, assignments, use of competitions). 
3. Technologies for teaching children self-management (self-analysis, self-assessment, self-monitoring, self-service, etc.).

4. Technologies for the use of incentives and punishments in the upbringing of children (forms, conditions and characteristics of incentives and punishments).

5. Team building and team building technology.

6. Children's diagnostic technologies (pedagogical diagnostics).

7. Technologies of individual work with children (children who are not mastered, children with special needs, work with gifted children, personal assistance, etc.).

8. Technologies of planning, analysis and evaluation of educational work (planning, control, analysis, evaluation, correction).

All of the above are generally studied theoretically in pedagogical classes. The task at hand is to learn how to apply this theoretical information in practice

Technologies for applying the principles of collaborative pedagogy in the educational process. The essence of collaborative pedagogy is to combine family and social education in order to achieve effective results of the educational process, to strengthen the educational influence of teachers and parents, and to turn students into teachers' assistants. With this in mind, the technologies used in the educational process should be in line with the essence of collaborative pedagogy. Because with their help, the teacher has to prepare his students to think independently, to live independently. Here are some tips on how to adapt and use some pedagogical technologies and innovative methods in the educational process.

Brainstorming is- a method of expressing ideas and thoughts on solving problems related to class life and social activities. For example, this method is very appropriate and 
effective in planning classes for the Kamolot Association in the classroom, preparing for some ceremonial public events, and other similar public issues. For example, if we ask students what they mean by "healthy person", we can get different answers: In the upper grades or in a group of students, we can ask a more complex question: "Where does the homeland begin?" and so on.

In addition to brainstorming, discussions, roundtables, and written discussions can be used extensively in educational work. Here are some ways in which students can discuss issues such as:

- rights and duties of young people;

- What should be the attitude of students to our president, the state symbols?

- The idea of national independence and youth;

- attitude to the state and other languages;

- What is a mandatory or alternative service?

- acts of sabotage by religious movements and terrorists;

- What are modern boys and girls proud of? and $h$.

It is also important to divide the class into smaller groups to further improve the educational process. This approach allows educators to explore the interests and needs of their students, and to identify and develop their capabilities and abilities. For example, the class (group) leader divides students into 3-5 small groups of 5-6 people based on the principle of stratification, and assigns them a specific area of social life in the classroom (reading, sports, work, leisure). acquisition, artistic decoration, etc.). Each subgroup should have a name, slogan, and emblem. The passport (business card) of such a small group can be as follows ${ }^{5}$ : 


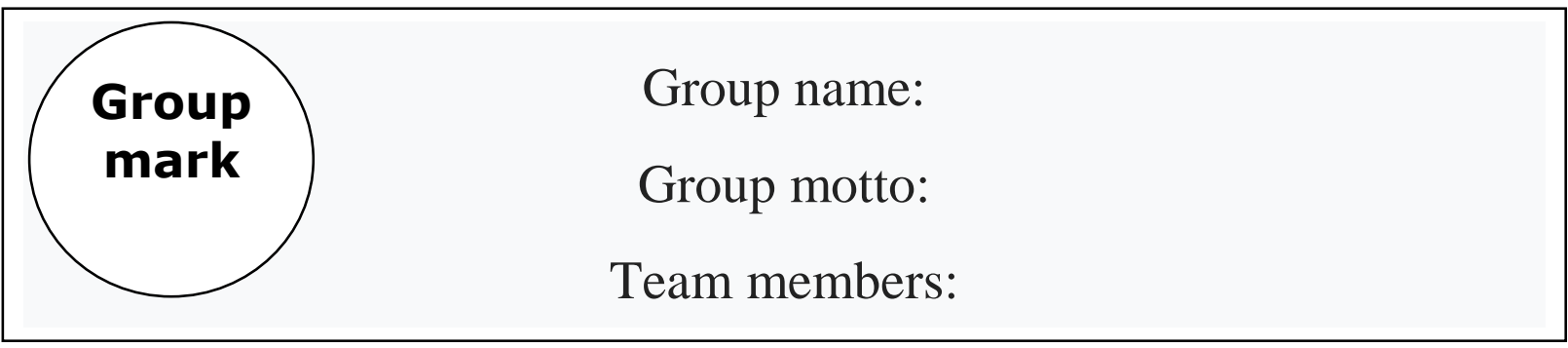

The choice of group name, slogan, emblem should take into account the age and interests of students.

The names "Rainbow", "Boychechak" and "Guncha" are suitable for children of primary school age. For older students, group names should be more complex. For example, they are called "Ziya", "Zukko", "Tinchlik", "Istiqlol", "Istiqbol", "Uchkun". A small group of commanders can be replaced quarterly or semi-annually. This allows each student to be both a leader and a subordinate.

The issues of spiritual and educational upbringing of school, lyceum and college students require a teacher to use the state symbols of the Republic of Uzbekistan widely and effectively. Therefore, from an early age, in the process of forming in students the right attitude to the President, the anthem, the flag, the coat of arms, the policy of the state, religious movements, the teacher uses specially prepared exhibitions, schemes, slides, films and videos. must be used effectively.

In the educational process, teachers use traditional methods to teach students; these include: monitoring, interviewing, visiting parents, and so on. In addition, during the parenting process, the educator uses a variety of questionnaires and tests to study the students in her class in collaboration with the school psychologist. In particular, modern 
education requires teachers to use diagnostic questionnaires and tests. Through such a questionnaire or test, the teacher has the opportunity to study the attitude of each student to study, work, people, himself and his personal qualities. For example, the teacher is his.

The choice of group name, slogan, emblem should take into account the age and interests of students.

The names "Rainbow", "Boychechak" and "Guncha" are suitable for children of primary school age. For older students, group names should be more complex ${ }^{6}$. For example, they are called "Ziya", "Zukko", "Tinchlik", "Istiqlol", "Istiqbol", "Uchkun". A small group of commanders can be replaced quarterly or semi-annually. This allows each student to be both a leader and a subordinate.

The issues of spiritual and educational upbringing of school, lyceum and college students require a teacher to use the state symbols of the Republic of Uzbekistan widely and effectively. Therefore, from an early age, in the process of forming in students the right attitude to the President, the anthem, the flag, the coat of arms, the policy of the state, religious movements, the teacher uses specially prepared exhibitions, schemes, slides, films and videos. must be used effectively.

In the educational process, teachers use traditional methods to teach students; these include: monitoring, interviewing, visiting parents, and so on. In addition, during the parenting process, the educator uses a variety of questionnaires and tests to study the students in her class in collaboration with the school psychologist. In particular, modern education requires teachers to use diagnostic questionnaires and tests. Through such a 
questionnaire or test, the teacher has the opportunity to study the attitude of each student to study, work, people, himself and his personal qualities. For example, the teacher is his

Ice-breaking is a way to improve people's relationships and get to know each other better. There are different types of ice cracks in the training process:

social experience (what assignments he had completed); who you want to be in the future, and $\mathrm{h}$. This method takes less time (2-3 minutes per person), but cannot be used in classes with 30 or more students. Interview - Choose pairs from unfamiliar students and give them 5-7 minutes to get to know each other. Each of them then introduces their partner to the whole class by adding one interesting piece of evidence about the person chosen by the teacher. This method allows you to introduce each student to the team. This method gives students persistence. This method is more time consuming than the previous method, but it cannot be used in classes of more than 25 people.

Table method. Can be used for collaborative classroom communities and to learn more about students. To use this method, the teacher gives each student a piece of paper, divides it into four parts, and asks each student to write the following information:

- express yourself in one word in the upper left corner;

- write something you are proud of in the upper right corner;

- reveal any secret about himself in the lower left corner (it does not have to be a serious secret, it must be a secret that no one around knows);

- Write down your favorite hobby in the lower right corner.

The teacher fills in the table at the same time as the participants. When students have finished their work, they meet each other by holding their tables (or hanging them 
on the wall) so that they can see them. This method does not take much time, but it allows the teacher to learn more about his students (especially if it is a new class).

All students in the class must be involved in the process. The use of these methods should take into account the age and knowledge of students, as well as the characteristics of the character, the results of debates and research should not affect their personality.

Role-playing requires the teacher to be familiar with the technology of role-playing. It's one of the only racing games I play. Before the game, the teacher (facilitator) explains the situation, informs about the typical behavior of the characters. Students use this information to volunteer for assigned roles. Therefore, it is necessary to choose the participants of the game carefully and skillfully.

Because the wrong choice or distribution of roles can also cause resentment or upset the "actors".

The role-playing method can be used, for example, in the following situations: "Amir Temur in a modern school (lyceum, college)", "You are among the heroes of the works of A. Navoi", etc. When creating a game, you need to create a situation where you can get to know the person playing it. At the end of the play, the teacher should focus on the purpose of the exercise, not on the specific statements made by the actors. This technology can also be used in several small groups, where members of a small group play roles in parallel and monitor and evaluate each other. This method requires the actors to study additional fiction and non-fiction, archival material, and film and television material. This, in turn, broadens students' worldviews, teaches them to think independently, and develops their imagination. However, in addition to the work organized 
in small groups in the current work, it is necessary to organize individual work. Because a student who is always working together may not feel confident when working alone. Therefore, we recommend that teachers use several other methods. One of them is the "2-part diary" method. Its essence is that the teacher offers students a few ideas on the board or in a special exhibition, and chooses one of them (the one you like the most) and asks them to comment. This method allows students to think independently, to express their views on worldly issues, the views of some celebrities, and to express their opinions.

\section{References}

1. Mirziyoyev Sh. Let's work together for the fate and future of our country. // "People's speech", June 16, 2017.

2. Yuldashev J.G., Usmanov S.A. Fundamentals of pedagogical technology. $-\mathrm{T}$.: Teacher, 2004. - 236 p.

3. Ochilov M. New pedagogical technologies. Against: Nasaf, 2000.

4. Tolipov OK, Usmonbaeva M. Applied bases of pedagogical technologies. -T .: "Fan", 2006.- 89 p.

5. Sattorova Z. and b. Technology: Textbook for 9th grade. -T .: "O'zbekiston", 2019. $-66 \mathrm{p}$.

6.Shomirzayev M.X. Ways to increase the effectiveness of technology teaching. $-\mathrm{T}$.: "Gold print edition", 2019. - 32 p.

7. Shomirzayev M.X. Genesis of formation and development technology of Uzbek national handicrafts.- T .: "Yangi Nashr", 2019. - 52 p. 
8. Shomirzayev M.X. Innovative processes in Uzbek national handicrafts. - T .: "New edition", 2019. - 88 p.

9. Shomirzayev M.X. Spectral-variable components of Uzbek national handicrafts.- T .: "Yangi Nashr", 2019. - 27 p.

10. Shomirzayev M.X., Karimov I.I. Innovative pedagogical technologies in teaching technology.- T .: "University", 2020. - 172-177 p. 